\title{
AkMen

\section{PENGARUH PEMBINAAN TERHADAP PRESTASI KERJA PEGAWAI PADA KANTOR PEKERJAAN UMUM PELAKSANAAN JALAN NASIONAL WILAYAH PROVINSI GORONTALO}

\author{
Poppy Mu'jizat \\ Jurusan Manajemen, Ichsan Gorontalo \\ e-mail :pmujizat3@gmail.com
}

\begin{abstract}
Abstrak
Penelitian ini bertujuan untuk mengetahui Pengaruh Pembinaan Terhadap Prestasi Kerja Pegawai Pada Kantor Pekerjaan Umum Pelaksanaan Jalan Nasional Wilayah Provinsi Gorontalo baik secara simultan maupun parsial. Pengumpulan data pokok yaitu melalui daftar pernyataan/pertanyaan yang diuji melalui uji validitas dan reabilitas setiap item pernyataan/pertanyaan yang terdapat pada daftar pernyataan/pertanyaan. Metode analisis yang digunakan adalah analisis jalur (Path Analisis) dengan terlebih dahulu memgkonfersi data skala ordinal ke skala interval. Objek dalam penelitian ini adalah Pembinaan, Prestasi Kerja.

Hasil hipotesis pertama menunjukan bahwa Pembinaan (X) Yakni Pembinaan Karir (X1) dan Pembinaan Disiplin (X2) Pembinaan Pendidikan dan Pelatihan (X3), secara simultan berpengaruh positif dan Signifikan terhadap Prestasi Kerja Pada Kantor Pekerjaan Umum Pelaksanaan Jalan Nasional Wilayah Provinsi Gorontalo sebasar 85,2\%. Sedangkan 14,8\% dipengaruhi oleh variabel lain yang tidak diteliti dalam model penelitian.

Hasil pengujian hipotesis kedua menunjukan bahwa Pembinaan (X) Yakni Pembinaan Karir (X1) dan Pembinaan Disiplin (X2) Pembinaan Pendidikan dan Pelatihan (X3), secara parsial berpengaruh positif dan Signifikan terhadap Prestasi Kerja Pada Kantor Pekerjaan Umum Pelaksanaan Jalan Nasional Wilayah Provinsi Gorontalo sub variabel Pembinaan Karir (X1) secara parsial berpengaruh positif dan signifikan terhadap Prestasi Kerja (Y) sebesar 18,2\%. Sub Pembinaan Disiplin (X2) secara parsial berpengaruh signifikan terhadap Prestasi Kerja (Y) sebesar 52,7\%. Sub Pembinaan Pendidikan dan Pelatihan (X3) secara parsial berpengaruh signifikan terhadap Prestasi Kerja (Y) sebesar 32,2\%.
\end{abstract}

Kata Kunci: Pembinaan, Prestasi Kerja.

\section{Abstract}

This study aims to determine the effect of coaching on employee performance at the Public Works Office for the Implementation of National Roads in Gorontalo Province either simultaneously or partially. Collecting main data is through a list of statements / questions tested through validity and reliability tests of each item of statement / question contained in the statement / question list. The analytical method used is path analysis by first converting the ordinal scale data to the interval scale. The object of this research is coaching, work performance.

The results of the first hypothesis show that Coaching $(X)$, namely Career Development (X1) and Discipline Development (X2) Education and Training Guidance (X3), simultaneously have a positive and significant effect on work performance at the Public Works Office for the 
Implementation of National Roads in Gorontalo Province area of $85,2 \%$. Meanwhile, $14.8 \%$ is influenced by other variables not examined in the research model.

The results of testing the second hypothesis show that Coaching $(X)$, namely Career Development (X1) and Discipline Development (X2) Education and Training Guidance (X3), partially have a positive and significant effect on work performance at the Public Works Office for the Implementation of National Roads in Gorontalo Province sub Career Development variable (X1) partially has a positive and significant effect on Job Performance (Y) by 18.2\%. Sub Discipline Development (X2) partially has a significant effect on Job Performance (Y) of $52.7 \%$. Education and Training Sub Development (X3) partially has a significant effect on Job Performance (Y) by $32.2 \%$.

Keywords: Coaching, Job Performance.

\section{PENDAHULUAN}

Berdasarkan pra penelitian yang peneliti lakukan pada Kantor Pekerjaan Umum Pelaksanaan Jalan Nasional Wilayah Provinsi Gorontalo. Diketahui bahwa prestasi kerja pegawai yang ada masih rendah hal ini dilihat dari beberapa pegawai yang kurang memiliki prestasi dalam bekerja hal ini indikasikan oleh tiga foktor yaitu kemampuan, kejelasan dan peran serta tingkat motivasi pegawai dalam bekerja. Masih terdapat pegawai yang belum memiliki kecakapan dalam memecahkan persoalan antar internal pegawai contoh masih sering salah paham dalam menyikapi suatu persoalan yang ada, masih belum sepenuhnya terjalin hubungan yang baik antara sesama pegawai, dan adanya pegawai yang belum mempunyai pengalaman dibidang tertentu contohnya keterlambatan atas pencapaian realisasi terhadap target rencana dalam hal kaitannya dengan fungsi waktu, dalam hal kejelasan dan peran masih ada pegawai yang pelaksanaan pekerjaannya belum sepenuhnya dilakukan kurang optimalnya penerapan fungsi manajemen ditatarkan pelaksanaan khususnya terkait dengan fungsi $5 \mathrm{M}$ Man,(Manajemen Tenaga) Money,(Manajemen Keuangan) Machine,(Manajemen Peralatan) Material (Manajemen Pengelolaan Material) Serta Method (Manajemen Metode Kerja/Pelaksanaan) terkesan belum sepenuhnya bertanggug jawab terhadap pekerjaannya. Dalam hal tingkat Motivasi masih terdapat pula pegawai yang belum termotivasi dalam hal meraih prestasi baik kepangkatan maupun jabatan.

Permasalahan di atas disebabkan oleh pembinaan yang belum terlaksana dengan baik, prosedur pembinaan yang ada pada Kantor Pekerjaan Umum belum sepenuhnya efektif. Dilihat dari pembinaan karir yang ada masih jauh dari apa yang diharapkan terutama dalam hal keterampilan dan tanggung jawab dari beberapa pegawai secara perspektif belum dapat menunjukkan loyalitas atau interest bagi kantor tersebut akan tetapi pegawai dapat menyelesaikan tugas dan fungsinya walaupun belum sesuai dengan target yang ditentukan disamping itu DIPA awal sebesar $73,86 \%$ juga sanagat berpengaruh terhadap dana SIAP, secara keseluruhan program/kegiatan yang direncanakan terealisasi sebesar $80,86 \%$ belum menunjukkan hasil yang maksimal. Disamping itu disiplin pegawai juga turut berpengaruh terhadap prestasi yang diberikannya masih ada beberapa pegawai yang secara keseluruhan belum dapat mematuhi segala peraturan yang ada terkadang masih lalai dalam bekerja, serta adanya program pembinaan pendidikan dan pelatihan yang dilaksakan terkadang masih ada beberapa pegawai yang belum dapat mengikuti pelatihan yang diberikan sehingga pegawai tersebut belum mampu dan siap bersaing dengan rekan kerjanya.Pada dasarnya 


\section{AkMen}

pembinaan diberikan agar pegawai memiliki kesadaran dan lebih bersemangat dan bergairah dalam bekerja.

\section{METODE PENELITIAN}

\section{Operasionalisasi Variabel Penelitian}

Dalam penelitian terdapat dua jenis variabel yang terdiri dari :

1. Variabel bebas (Independent) yaitu Pembinaan Karir (X1) dan Pembinaan Disiplin (X2) Pembinaan Pendidikan dan Pelatihan (X3).

2. Variabel tidak bebas (Dependent) yaitu Prestasi Kerja Pegawai (Y)

Variabel diatas dapat dilihat lebih jelas pada table berikut ini :

Tabel 3.1 Operasionalisasi Variabel Penelitian

\begin{tabular}{|c|c|c|c|}
\hline Variabel & Sub Variabel & Indikator & Skala \\
\hline \multirow{3}{*}{$\begin{array}{c}\text { Pembinaan } \\
\text { (X) }\end{array}$} & $\begin{array}{l}\text { Pembinaan } \\
\text { Karir } \\
\text { (X1) }\end{array}$ & $\begin{array}{ll}\text { 1. } & \text { Kecakapan } \\
\text { 2. Keterampilan } \\
\text { 3. } \\
\text { 4. Kesa kerja (lama bekerja) } \\
\text { 5. Ketaatan (loyalitas) } \\
\text { 6. Tanggung jawab } \\
\text { 7. } \\
\text { Interest (minat) } \\
\end{array}$ & Ordinal \\
\hline & $\begin{array}{l}\text { Pembinaan } \\
\text { Disiplin } \\
\text { (X2) }\end{array}$ & 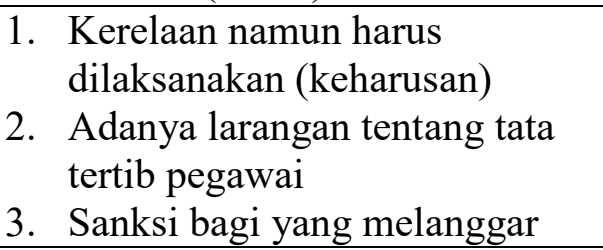 & Ordinal \\
\hline & $\begin{array}{l}\text { Pembinaan } \\
\text { Pendidikan } \\
\text { Dan Pelatihan } \\
\text { (X3) }\end{array}$ & $\begin{array}{l}\text { 1. Preservice training, } \\
\text { 2. Inservice training, } \\
\text { 3. Kemampuan dalam mengikuti } \\
\text { pelatihan kerja }\end{array}$ & Ordinal \\
\hline
\end{tabular}

Sumber Variabel X1: Domi C. Matutina dkk. (2013:98)

Tabel 3.2 Operasionalisasi Variabel Penelitian Y

\begin{tabular}{|c|c|c|c|}
\hline \multirow{3}{*}{$\begin{array}{l}\text { Prestasi } \\
\text { Kerja } \\
\text { (Y) }\end{array}$} & 1. Kemampuan & $\begin{array}{ll}\text { - } & \text { Kecakapan karyawan dalam } \\
\text { memecahkan persoalan } \\
\text { - } & \text { Kesesuaian antara individu dan } \\
\text { karyawan } \\
\text { - } & \text { Pegalaman kerja }\end{array}$ & Ordinal \\
\hline & $\begin{array}{l}\text { 2. Kejelasan dan } \\
\text { peranan }\end{array}$ & $\begin{array}{ll}\text { - } & \text { Pelaksanaan pekerjaan } \\
\text { - } & \text { Disiplin waktu } \\
\text { - } & \text { Tanggung jawab }\end{array}$ & Ordinal \\
\hline & $\begin{array}{l}\text { 1. Tingkat motivasi } \\
\text { kerja }\end{array}$ & $\begin{array}{ll}- & \text { Kerja sama } \\
\text { - } & \text { Kepuasan kerja }\end{array}$ & Ordinal \\
\hline
\end{tabular}

Sumber Variabel Y : Sutrisno (2009:151) 


\section{Pengujian Instrumen Penelitian}

Metode analisis data yang di gunakan adalah metode kuantitatif yang di lakukan dengan membahas dan membuat presentase dari hasil jawaban responden. Untuk mendapatkan data yang baik dalam arti mendekati kenyataan (objektif) sudah tentu di perlukan suatu instrumen atau alat ukur yang valid dan andal (reliable). Dan untuk dapat meyakini bahwa instrumen atau alat ukuryang valid dan andal, maka instrumen tersebut sebelum digunakan harus diuji validitas dan reliabilitasnya sehingga apabila digunakan akan menghasilkan hasil yang objektif.

\section{Uji Validitas}

Pengujian vadilitas instrumen dengan menguji validitas konstruksi (construct validity), maka dapat di gunakan pendapat dari ahli (judgment experts), setelah instrumen dikonstruksikan dengan para ahli dengan cara di mintai pendapatnya tentang instrument yang telah di susun itu. Hal ini sependapat dengan Sugiyono (2010:114) mengatakan bahwa "Setelah pengujian konstruksi selesai dari para ahli, maka di teruskan uji coba instrument. Instrument yang telah di setujui para ahli tersebut dicobakan pada sampel di mana populasi di ambil. Setelah data didapat dan ditabulasikan, maka pengujian validitas konstruksi dilakukan dengan analisis faktor, yaitu dengan mengkorelasikan antar skor instrument."

Uji validitas di lakukan dengan mengkorelasikan masing-masing pernyataan dengan jumlah skor untuk masing-masing variabel. Selanjutnya dengan memberikan interprestasi terhadap koefisien korelasi. Untuk pengujian validitas peneliti dengan menggunakan rumus korelasi seperti yang dikemukakan oleh Pearsonyang di kenal dengan rumus korelasi Pearson Product Moment (PPM) sebagai berikut.

Dimana:

$$
r X Y=\frac{\mathrm{n}\left(\sum \mathrm{XY}\right)-\left(\sum \mathrm{X}\right) \cdot\left(\sum \mathrm{Y}\right)}{\sqrt{\left\{\mathrm{n} \cdot \sum \mathrm{X}^{2}\right\}} \cdot\left\{\mathrm{n} \cdot \sum \mathrm{Y}^{2}-\left(\sum \mathrm{Y}\right)^{2}\right.}
$$

$\mathrm{r} \quad=$ Angka korelasi

$\mathrm{X}=$ Skor pertanyaan (ke-n) variabel $\mathrm{X}$

$\mathrm{Y}=$ Skor pertanyaan (ke-n) variabel $\mathrm{Y}$

$\mathrm{n}=$ Jumlah responden

$\mathrm{XY}=$ Skor pertanyaan dikali total pertanyaan

Dalam hasil analisis item teknik korelasi untuk menentukan validitas item ini sampai sekarang merupakan teknik yang paling banyak digunakan". Selanjutnya dalam memberikan interpretasi terhadap koefisien korelasi, Masrun menyatakan "Item yang mempunyai korelasi positif dengan kriterium (skor total) serta korelasi yang tinggi, menunjukkan bahwa item tersebut mempunyai validitas yang tinggi pula. Biasanya syarat minimum dianggap valid adalah $r=0,3$ ". Jika korelasi antara butir dengan skor total $<$ 0,3 maka butir dalam instrumen tersebut dinyatakan tidak valid, sebaliknya jika korelasi antara butir dengan skor total $>0,3$ maka butir dalam instrumen tersebut dinyatakan valid. Kriteria korelasi Pearson Product Moment (PPM) dapat dilihat pada table berikut:

Tabel 3. Koefisien Korelasi

\begin{tabular}{|c|c|}
\hline $\mathbf{R}$ & Keterangan \\
\hline $0,800-1,000$ & Sangat tinggi / Sangat Kuat \\
\hline $0,600-0,799$ & Tinggi / Kuat \\
\hline $0,400-0,599$ & Cukup tinggi / Sedang \\
\hline
\end{tabular}




\begin{tabular}{|l|c|}
\hline $0,200-0,399$ & Rendah / Lemah \\
\hline $0,000-0,199$ & Sangat rendah / Sangat Lemah \\
\hline
\end{tabular}

Sumber : Riduwan (20011:280).

\section{Uji Reliabilitas}

Uji Reliabilitas menunjuk pada suatu pengertian bahwa sesuatu instrumen cukup dapat di percaya untuk di gunakan sebagai alat pengumpul data karena instrumen tersebut sudah baik. Instrumen yang baik tidak akan bersifat tendensius mengarahkan responden untuk memilih jawaban-jawaban tertentu. Instrumen yang sudah dapat dipercaya, yang reliabel akan menghasilkan data yang dapat di percaya juga. Apabila datanya memang benar sesuai dengn kenyataannya, maka berapa kalipun diambil, tetap akan sama. Untuk menghitung uji reliabilitas, penelitian ini menggunakan rumus alpha cronbach menurut Sugiono (2007:354) dengan rumus sebagai berikut :

Keterangan :

$$
a=\left(\frac{k}{k-1}\right)\left(1 \frac{\sum s i}{s t}\right)
$$

$$
\begin{array}{lll}
\mathrm{k} & = & \text { Jumlah instrument pertanyaan } \\
\sum_{\mathrm{Si}}{ }^{2} & = & \text { Jumlah varians dalam setiap instrumen } \\
\mathrm{S} & = & \text { Varians keseluruhan instrument }
\end{array}
$$

Suatu variabel di katakan reliable jika memberikan nilai cronbach alpha $>0,60$ dan jika nilai cronbach alpha $<0,60$ dikatakan tidak reliable (Ghozila, 2005:46). Semakin nilai alphanya mendekati satu maka nilai reliabilitas datanya semakin terpercaya.

\section{Metode Analisis Data}

Untuk memastikan sub-sub variabel apakah ada pengaruh Pembinaan (X) Yakni Pembinaan Karir (X1) dan Pembinaan Disiplin (X2) Pembinaan Pendidikan dan Pelatihan (X3) terhadap Prestasi Kerja Pegawai, maka pengujian di lakukan dengan uji analisis jalur (Path Analisys), dengan terlebih dahulu mengkonversi data skala ordinal ke skala interval melalui Method Successive Interval (MSI). Analisis jalur di gunakan dengan pertimbangan bahwa pola hubungan antar variabel dalam penelitian adalah bersifat korelatif dan kualitas.

Hipotesis penelitian diperlihatkan melalui struktur hubungan antara variabel independen dengan variabel dependen dangan diagram jalur dapat di lihat pada struktur jalur berikut ini :

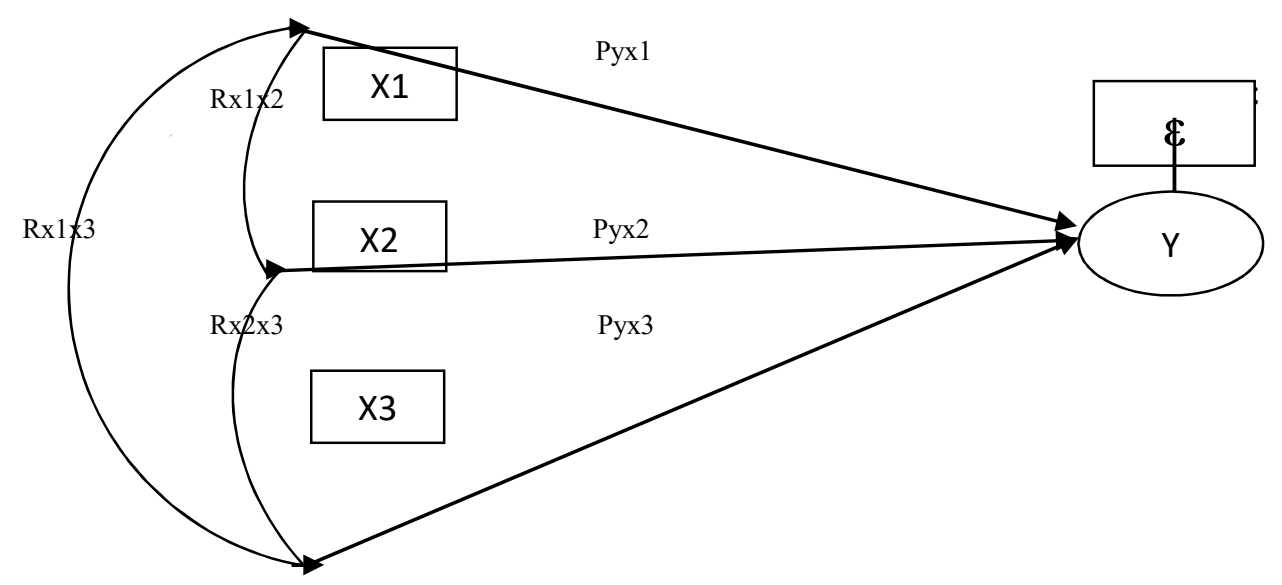

Gambar 3.2 Struktur Path analisis 


\section{AkMen}

\section{HASIL DAN PEMBAHASAN}

Hasil analisis statistik yang menggunakan analisis jalur tersebut akan diketahui apakah varibel-varibel bebas (Independen) baik secara simultan maupun secara parsial memberikan pengaruh yang nyata (signifikan) terhadap variabel terikat (dependen). Berdasarkan hasil pengolahan data atas 68 orang responden dengan menggunakan analisis jalur, maka diperoleh persamaan sebagai berikut:

$$
\mathrm{Y}=0,182 \mathrm{X} 1+0,527 \mathrm{X} 2+0,322 \mathrm{X} 3+0,148 \varepsilon
$$

Dari persamaan diatas, menunjukkan bahwa koefisien sub variabel independen yakni Pembinaan Karir (X1) yang diukur memiliki pengaruh yang positf dan signifikan terhadap Prestasi Kerja (Y). Besarnya pengaruh Pembinaan secara langsung terhadap Prestasi Kerja sebesar 0,182 atau 18,2\%

X2 = Pembinaan Disiplin, menandakan bahwa Pembinaan Disiplin (X2), yang diukur memiliki pengaruh yang positif dan signifikan terhadap Prestasi Kerja (Y). Besarnya pengaruh Pembinaan Disiplin yang secara langsung terhadap Prestasi Kerja sebesar 0,527 atau $52,7 \%$.

X3 = Pembinaan Pendidikan dan Pelatihan, menandakan bahwa Pembinaan Pendidikan dan Pelatihan (X3), yang diukur memiliki pengaruh yang positif dan signifikan terhadap Prestasi Kerja (Y). Besarnya pengaruh Pembinaan Pendidikan dan Pelatihan yang secara langsung terhadap Prestasi Kerja sebesar 0,322 atau 32,2\%.

Sedangkan $\varepsilon=0,148$ menunjukkan bahwa terdapat variabel-variabel lain yang tidak diteliti dalam penelitian ini sebesar $14,8 \%$.

Memperhatikan hasil perhitungan analisis jalur yang terdapat pada lampiran, maka hasil analisis tersebut dapat di interpretasikan bahwa Nilai Koefisien Determinasi (R Square) sebesar 0,852 ini berarti sekitar $85,2 \%$ pengaruh yang ada terhadap Prestasi Kerja oleh variabel Pembinaan Serta masih ada sekitar 14,8\% ditentukan oleh variabel lain dan masih memerlukan penelitian lebih lanjut.

Berdasarkan hasil olahan data yang menggunakan analisis jalur hubungan antar variabel dapat dilihat pada gambar di bawah ini, model struktural jalur sebagai berikut:

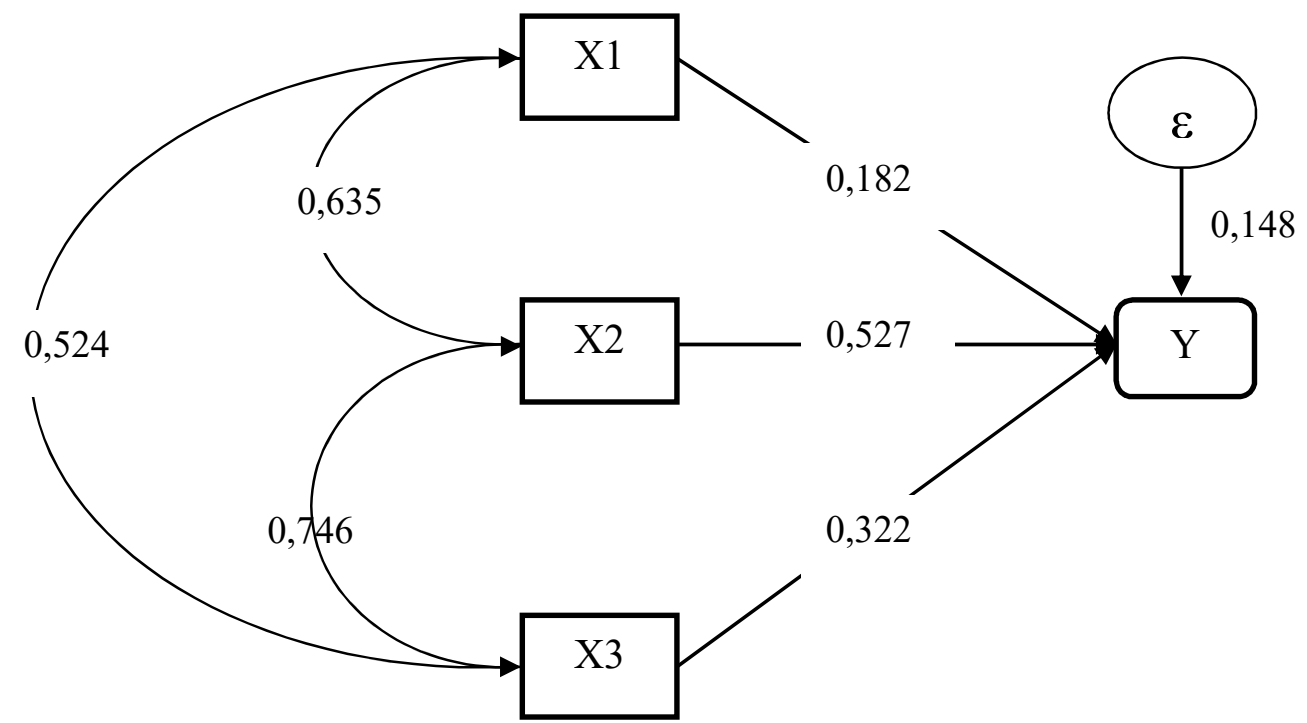

Gambar 4.2: Hasil Estimasi Struktur Analisis Jalur 
Sebagai hasil analisis dari variabel independen tersebut diperoleh informasi bahwa yang berpengaruh adalah sub Variabel Pembinaan Karir (X1) dengan nilai sebesar 0,182 terhadap Prestasi Kerja, sub variabel Pembinaan Disiplin (X2) yang dominan berpengaruh dengan besar 0,527 terhadap Prestasi Kerja (Y), dan sub variabel Pembinaan Pendidikan dan Pelatihan (X3) dengan besar pengaruh sebesar 0,322 terhadap Prestasi $\operatorname{Kerja}(\mathrm{Y})$.

Hasil penelitian diatas dapat di ringkas seperti pada tabel 4.14 sebagai berikut :

Tabel 4.10 Koefisien jalur, pengaruh langsung, pengaruh total dan pengaruh (X1), (X2), dan (X3) secara simultan dan parsial terhadap variabel (Y)

\begin{tabular}{|c|c|c|c|c|c|}
\hline \multirow[b]{2}{*}{ Variabel } & \multirow{2}{*}{$\begin{array}{l}\text { Koefisien } \\
\text { Jalur }\end{array}$} & \multicolumn{3}{|c|}{ Pengaruh } & \multirow{2}{*}{$\begin{array}{c}\text { Kontribusi } \\
\text { Bersama } \\
\left(\mathbf{R}^{2}\right)\end{array}$} \\
\hline & & Langsung & $\begin{array}{c}\text { Tidak } \\
\text { Langsung }\end{array}$ & Total & \\
\hline $\mathbf{X 1}$ & $\mathrm{X}_{1}$ Terhadap Y & 0,182 & - & $18,2 \%$ & \multirow{6}{*}{$\begin{array}{c}0,148 \\
\text { Atau } \\
14,8 \%\end{array}$} \\
\hline $\mathbf{X 2}$ & $\mathrm{X}_{2}$ Terhadap Y & 0,527 & - & $52,7 \%$ & \\
\hline $\mathbf{X 3}$ & $\mathrm{X}_{3}$ Terhadap Y & 0,322 & - & $32,2 \%$ & \\
\hline$€$ & \multicolumn{3}{|c|}{ Pengaruh Variabel luar Terhadap Y } & 14,8 & \\
\hline \multicolumn{4}{|c|}{ X1, X2, X3 Terhadap Y } & $85,2 \%$ & \\
\hline \multicolumn{4}{|c|}{ Total } & $100 \%$ & \\
\hline
\end{tabular}

\section{Regression}

Variables Entered/Removed ${ }^{\mathrm{a}}$

\begin{tabular}{|l|l|c|l|}
\hline Model & Variables Entered & $\begin{array}{l}\text { Variables } \\
\text { Removed }\end{array}$ & Method \\
\hline 1 & $\mathrm{X} 3, \mathrm{X} 1, \mathrm{X} 2^{\mathrm{b}}$ & & Enter \\
\hline
\end{tabular}

a. Dependent Variable: $Y$

b. All requested variables entered.

Model Summary

\begin{tabular}{|l|r|r|r|c|}
\hline Model & $\mathrm{R}$ & $\mathrm{R}$ Square & \multicolumn{1}{|c|}{$\begin{array}{c}\text { Adjusted } \mathrm{R} \\
\text { Square }\end{array}$} & $\begin{array}{c}\text { Std. Error of the } \\
\text { Estimate }\end{array}$ \\
\hline 1 &, $923^{\mathrm{a}}$ &, 852 &, 845 & 1,566 \\
\hline
\end{tabular}

a. Predictors: (Constant), X3, X1, X2

ANOVA $^{a}$

\begin{tabular}{|rl|r|r|r|r|r|}
\hline Model & & Sum of Squares & Df & Mean Square & F & Sig. \\
\hline \multirow{2}{*}{1} & Regression & 901,420 & 3 & 300,473 & 122,595 &, $000^{\mathrm{b}}$ \\
& Residual & 156,860 & 64 & 2,451 & & \\
& Total & 1058,279 & 67 & & & \\
\hline
\end{tabular}

a. Dependent Variable: $Y$

b. Predictors: (Constant), X3, X1, X2

Coefficients $^{a}$

\begin{tabular}{|c|c|c|c|c|c|c|}
\hline \multirow[t]{2}{*}{ Mod } & & \multicolumn{2}{|c|}{ Unstandardized Coefficients } & \multirow{2}{*}{$\begin{array}{c}\begin{array}{c}\text { Standardized } \\
\text { Coefficients }\end{array} \\
\text { Beta }\end{array}$} & \multirow[t]{2}{*}{$\mathrm{t}$} & \multirow[t]{2}{*}{ Sig. } \\
\hline & & $B$ & Std. Error & & & \\
\hline \multirow{4}{*}{1} & (Constant) & 6,526 & 1,671 & & 3,904 &, 000 \\
\hline & $\mathrm{X} 1$ & ,240 & 082 & , 182 & 2,914 & ,005 \\
\hline & $\mathrm{X} 2$ & 1,039 & , 158 &, 527 & 6,582 &, 000 \\
\hline & X3 & 804 & ,182 & 322 & 4,429 & ,000 \\
\hline
\end{tabular}


Hal. 450 - 463

e-ISSN : 2621-4377 \& p-ISSN : 1829-8524

Hbmepage: https//e-jurnal.stienobel-indonesiaacid/index.php/akmen

\begin{tabular}{|l|r|r|r|r|r|}
\hline & PembinaanKarir & $\begin{array}{c}\text { PembinaanDisipl } \\
\text { in }\end{array}$ & $\begin{array}{c}\text { PembinaanPend } \\
\text { idikanDanPelatih } \\
\text { an }\end{array}$ & PrestasiKerja \\
\hline $\begin{array}{lllr}\text { Series or Sequence Length } \\
\text { Number of Missing Values in User-Missing }\end{array}$ & 68 & 68 & 68 & 0 \\
the Plot & System-Missing & 0 & 0 & 0 \\
\hline
\end{tabular}

The cases are unweighted.

Estimated Distribution Parameters

\begin{tabular}{|rl|r|r|r|r|}
\hline & PembinaanKarir & $\begin{array}{c}\text { PembinaanDisipl } \\
\text { in }\end{array}$ & $\begin{array}{c}\text { PembinaanPend } \\
\text { idikanDanPelatih } \\
\text { an }\end{array}$ & PrestasiKerja \\
\hline Normal Distribution & Location & 21.235 & 12.809 & 12.647 & 35.103 \\
& Scale & 3.0179 & 2.0168 & 1.5907 & 3.9743 \\
\hline
\end{tabular}

The cases are unweighted.

\section{Pembinaan Karir}

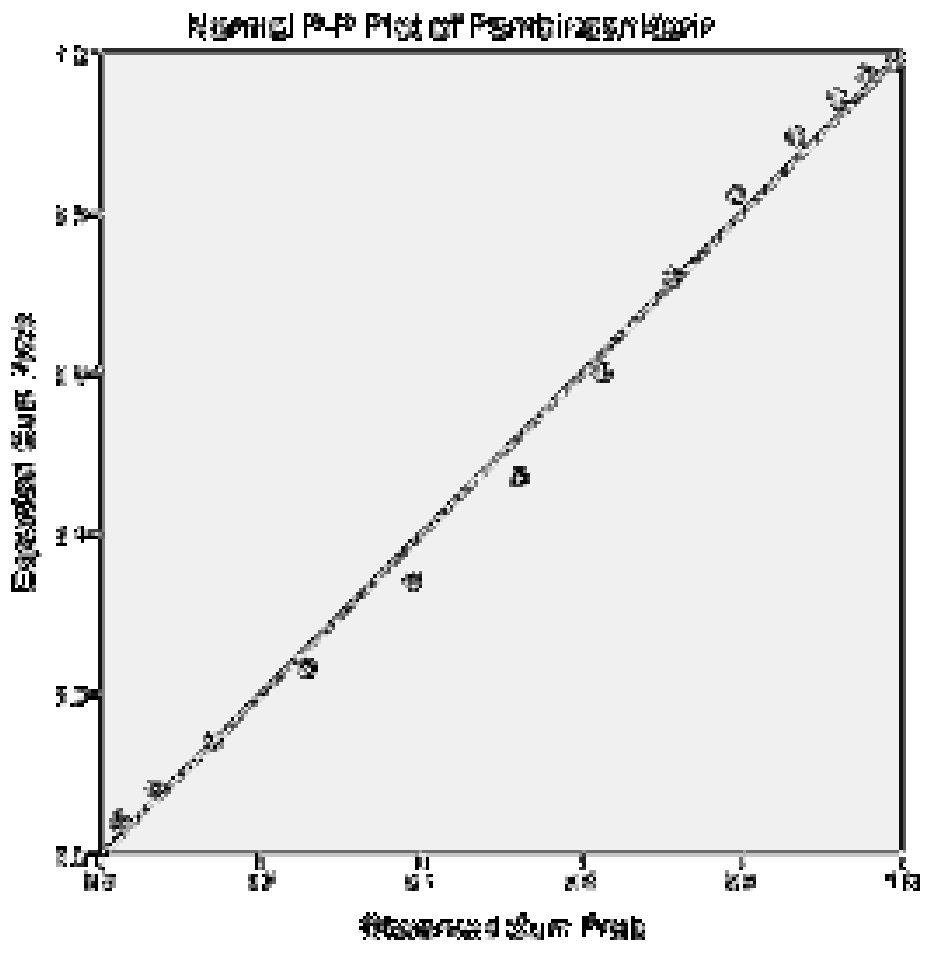


Hal. 450 - 463

e-ISSN : 2621-4377 \& p-ISSN : 1829-8524

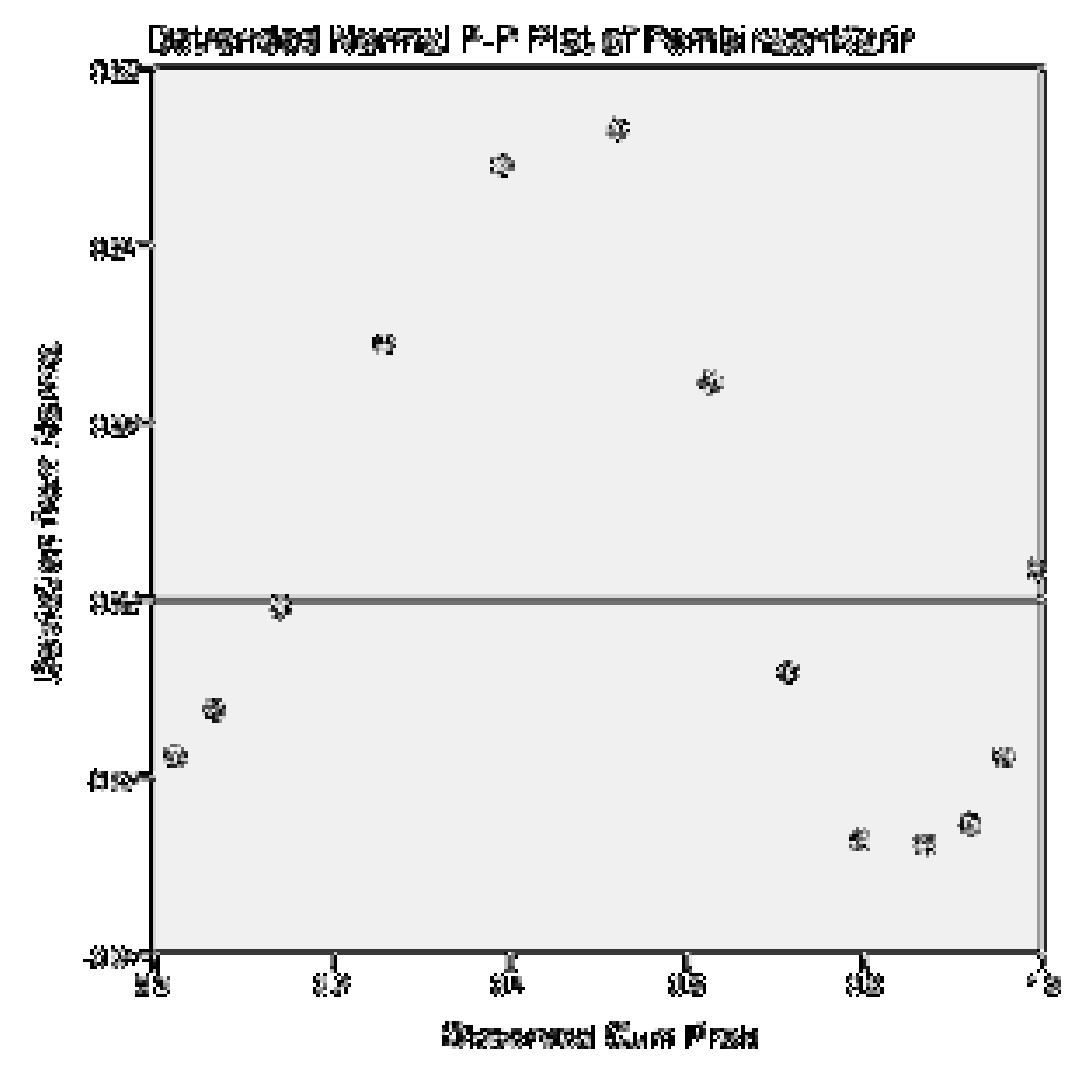

\section{PembinaanDisiplin}

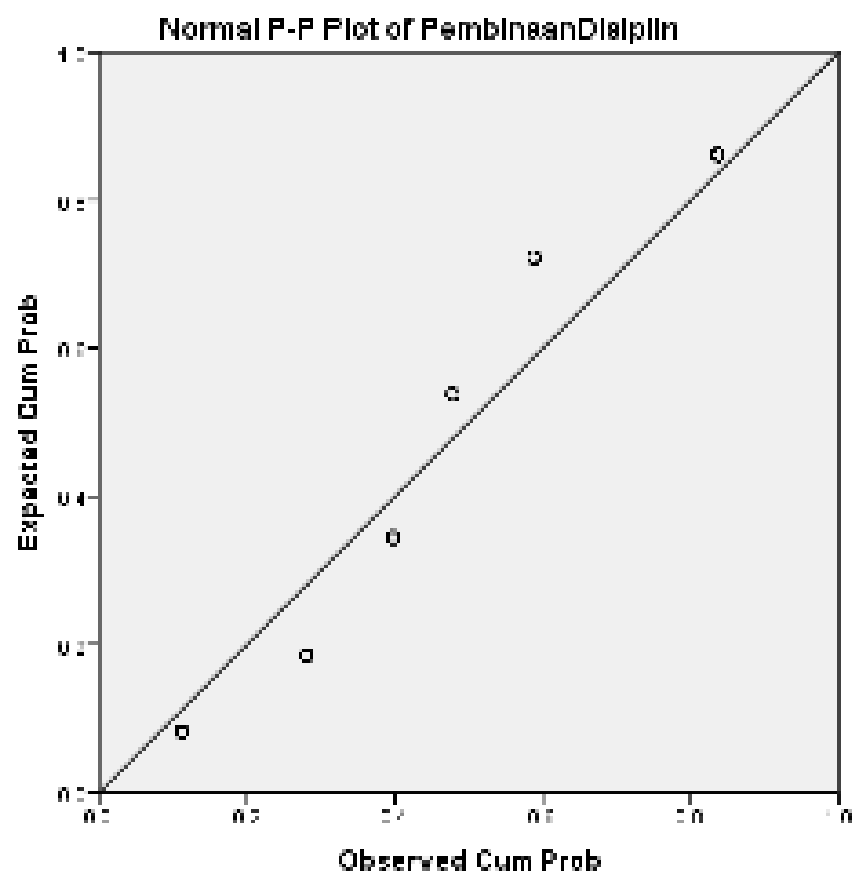




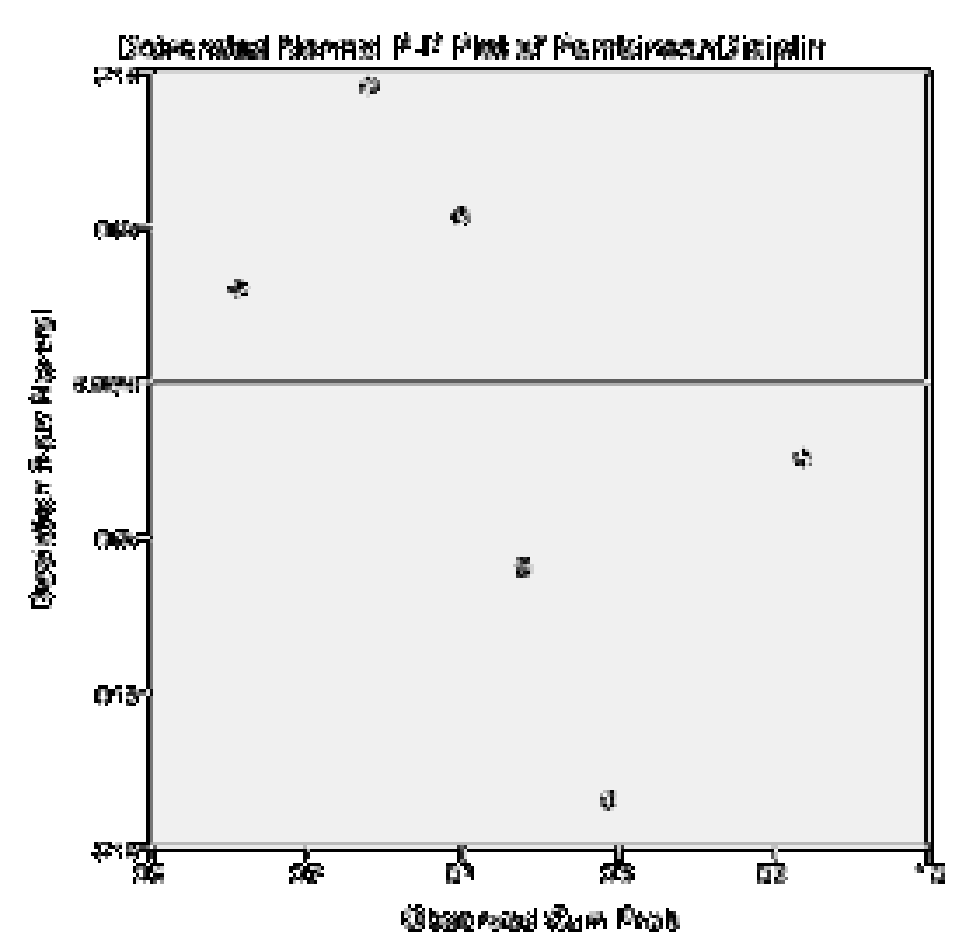

\section{Pembahasan}

A. Pembinaan (X) yang terdiri dari Pembinaan Karir (X1), Pembinaan Disiplin (X2), dan Pembinaan Pendidikan dan Pelatihan (X3) secara Parsial berpengaruh positif dan signifikan terhadap Prestasi Kerja (Y)

\section{Pembinaan Karir (X1) berpengaruh positif dan signifikan terhadap Prestasi Kerja (Y)}

Berdasarkan dari hasil penelitian terhadap Prestasi Kerja responden menunjukan bahwa secara parsial terdapat pengaruh langsung positif dan signifikan antara sub Variabel Pembinaan Karir (X1) terhadap Prestasi Kerja (Y) Hal ini menunjukan bahwa dengan Pembinaan (X) melalui Pembinaan Karir (X1) yang diterapkan oleh kantor maka dapat menghasilkan Prestasi Kerja (Y) yang baik pada Pekerjaan Umum Pelaksanaan Jalan Nasional Wilayah Provinsi Gorontalo menjadi faktor pendukung sekaligus terendah dalam Pembinaan.

Pengaruh signifikan ini menunjukan bahwa Pada Pekerjaan Umum Pelaksanaan Jalan Nasional Wilayah Provinsi Gorontalo Sub Variabel Pembinaan Karir yaitu kurangnya pegawai yang memiliki kemampuan kecakapan dalam bekerja sehingga masih ada beberapa tugas yang belum terselesaikan, dalam hal keterampilan dan tanggung jawab dari beberapa pegawai secara perspektif belum dapat menunjukkan loyalitas atau interest bagi kantor tersebut masih ada pegawai yang memiliki masa kerja lama (senioritas) belum mampu bekerja secara professional belum secara eseluruhan memiliki ketaatan dan tanggung jawab penuh terhadap pekerjaannya kadang melimpakan kesalahanya kepada orang lain, akan tetapi pegawai dapat menyelesaikan tugas dan fungsinya walaupun belum sesuai dengan target yang ditentukan disamping itu DIPA awal juga sanagat berpengaruh terhadap dana SIAP, secara keseluruhan program/kegiatan yang direncanakan terealisasi belum menunjukkan hasil yang maksimal. 
Penelitian ini sesuai dengan teori yang dikemukakan oleh Domi C. Matutina dkk. (2013:98) Dalam rangka upaya meningkatkan mutu, keterampilan kerja, memupuk kegairahan kerja atau semangat kerja pegawai, maka pembinaan pegawai harus dilaksanakan atas dasar perpaduan sistem karir dan sistem prestasi kerja. Sistem karir adalah suatu sistem manajemen personalia, dimana untuk pengangkatan pertama didasarkan atas kecakapan dan keterampilan yang bersangkutan, bidang pengembangan lebih lanjut masa kerja (lama bekerja), kesetiaan (loyalitas), ketaatan, tanggung jawab, interest (minat) terhadap tugas yang dibebankan dan syarat-syarat lainnya.

Irma Ika Melati (2011). Dengan judul Pengaruh Pembinaan Terhadap Prestasi kerja Pegawai (Studi Empiris Pada Kementerian Keuangan Kantor Wilayah Jawa Tengah). Hasil penelitian ini menunjukkan bahwa Pembinaan karir berpengaruh positif dan signifikan terhadap Prestasi Kerja pada Kementerian Keuangan Kantor Wilayah Jawa Tengah). Pembinaan karir akan mampu meningkatkan prestasi kerja pabila diterapkan secara maksimal dan secara menyeluruh dengan otomatis prestasi kerja pegawai kan meningkat.

\section{Pembinaan Disiplin (X2) berpengaruh positif dan signifikan terhadap Prestasi Kerja (Y)}

Berdasarkan dari hasil penelitian terhadap Prestasi Kerja responden menunjukan bahwa secara parsial terdapat pengaruh langsung positif dan signifikan antara sub variabel Pembinaan Disiplin (X2) terhadap Prestasi Kerja(Y). Hal ini menunjukan bahwa dengan Pembinaan (X) melalui Pembinaan Disiplin (X2) pada kantor maka akan semakin baik pula Prestasi Kerja (Y) pada Pekerjaan Umum Pelaksanaan Jalan Nasional Wilayah Provinsi Gorontalo menjadi faktor utama dalam penelitian ini.

Pengaruh signifikan ini menunjukan bahwa Pada Pekerjaan Umum Pelaksanaan Jalan Nasional Wilayah Provinsi Gorontalo sub variabel Pembinaan Disiplin pegawai sangat berpengaruh terhadap prestasi yang diberikannya sanksi yang diberikan bersifat obyektif (sesuai dengan pelanggaran yang dilakukan dalam hal ini masih ada beberapa pegawai yang belum dapat mematuhi segala peraturan yang ada terkadang masih lalai dalam bekerja, akan tetapi pekerjaan yang dikerjakan pegawai dapat dikerjaan walaupun memerlukan sedikit waktu untuk menyelesaikannya, Pimpinan menerapkan berbagai ketentuan yang berlaku secara efektif adanya keharusan pegawai bekerja dengan penuh kerelaan terhadap pekerjaan yang diembanya, pegawai selalu tahu akan adanya peraturan yang dibuat suatu instansi atau pimpinan menerapkan berbagai ketentuan yang berlaku secara efektif, serta setiap sanksi yang diberikan mempunyai nilai pelajaran apabila pegawai melakukan pelanggaran atau kesalahan sanksi yang diberikan terhadap pegawai selalu memiliki nilai kerja. .

Penelitian ini sesuai dengan teori yang dikemukakan oleh Domi C. Matutina dkk. (2013:98) disiplin yaitu suatu sikap mental yang mantap yang mengandung kerelaan kewajiban atau kekerasan untuk mematuhi atau mentaati segala peraturan perundangundangan, norma-norma yang berlaku dan telah disepakati bersama. Adanya kerelaan namun harus dilaksanakan (keharusan), adanya larangan, sanksi bagi yang melanggar.

Irma Ika Melati (2011) . Dengan judul Pengaruh Pembinaan Terhadap Prestasi kerja Pegawai (Studi Empiris Pada Kementerian Keuangan Kantor Wilayah Jawa Tengah). Hasil penelitian ini menunjukkan bahwa Disiplin pegawai berpengaruh positif dan signifikan terhadap Prestasi Kerja pada Kementerian Keuangan Kantor Wilayah Jawa Tengah). disiplin akan mampu meningkatkan prestasi kerja apabila diterapkan secara 
maksimal dan secara menyeluruh dengan otomatis prestasi kerja pegawai akan meningkat pula.

\section{Pembinaan Pendidikan dan Pelatihan (X3) berpengaruh positif dan signifikan terhadap Prestasi Kerja (Y)}

Berdasarkan dari hasil penelitian terhadap Prestasi Kerja responden menunjukan bahwa secara parsial terdapat pengaruh langsung positif dan signifikan antara sub variabel Pembinaan Pendidikan dan Pelatihan (X3) terhadap Prestasi Kerja (Y). Hal ini menunjukan bahwa semakin baikPembinaan (X) melalui Pembinaan Pendidikan dan Pelatihan (X3) pada kantor maka akan semakin baik pula Prestasi Kerja (Y) pada Pekerjaan Umum Pelaksanaan Jalan Nasional Wilayah Provinsi Gorontalo menjadi faktor pendukung dalam penelitian ini.

Pengaruh signifikan ini menunjukan bahwa Pada Pekerjaan Umum Pelaksanaan Jalan Nasional Wilayah Provinsi Gorontalo sub variabel Pembinaan Pendidikan dan Pelatihan yaitu adanya program pembinaan pendidikan dan pelatihan yang dilaksakan terkadang kantor memberikan pelatihan kepada setiap pegawai baru, masih ada beberapa pegawai yang belum dapat mengikuti pelatihan yang diberikan sehingga pegawai tersebut belum mampu dan siap bersaing dengan rekan kerjanya, dalam pembinaan pendidikan dan pelatihan pimpinan berupayah untuk meningkatkan mutu, keahlian, serta kemampuan dalam mengituti pelatihan kerja akan tetapi dalam hal ini kurangnya kemampuan pegawai dalam mengikuti pelatihan kerja, serta setiap pegawai belum mampu mengikuti pelatihan belum memahami akan pelatihan yang diberikan terkadang hanya sibuk akan Hand Phone yang digenggamnya. Pada dasarnya pembinaan diberikan agar pegawai memiliki kesadaran dan lebih bersemangat dan bergairah dalam bekerja.

Penelitian ini sesuai dengan teori yang dikemukakan oleh Rudiatin (2011) Dengan judul Pengaruh Pengaruh Pembinaan Terhadap Prestasi kerja Pegawai pada Dinas Pendidikan, Pemuda, dan Olahraga Provinsi Daerah Istimewa Yogyakarta. Hal iniberarti bahwa Pembinaan Pendidikan dan Pelatihan (X3) berpengaruh positif terhadap Prestasi Kerja (Y). ".Hasil Penelitiannya adalah pembinaan Pendidikan dan Pelatihan (X3) secara simultan berpengaruh positif terhadap Prestasi Kerja. Hal ini berarti mengindikasikan bahwa pembinaan Pendidikan dan Pelatihan yang baik dan berkesinambungan serta pemberian motivasi kerja yang baik tepat akan meningkatkan prestasi kerja Pegawai pada Dinas Pendidikan, Pemuda, dan Olahraga Provinsi Daerah Istimewa Yogyakarta.

\section{KESIMPULAN}

Dari hasil penelitian dan analisis pembahasan yang dilakukan, maka dapat dikemukakan kesimpulan sebagai berikut:

1. Pembinaan (X) Yakni Pembinaan Karir (X1) dan Pembinaan Disiplin (X2) Pembinaan Pendidikan dan Pelatihan (X3) secara simultan berpengaruh positif dan signifikan terhadap Prestasi kerja pegawai pada Kantor Pekerjaan Umum Pelaksanaan Jalan Nasional Wilayah Provinsi Gorontalo.

2. Pembinaan (X) Yakni Pembinaan Karir (X1) secara parsial berpengaruh positif dan signifikan terhadap Prestasi kerja pegawai pada Kantor Pekerjaan Umum Pelaksanaan Jalan Nasional Wilayah Provinsi Gorontalo.

3. Pembinaan (X) Yakni Pembinaan Disiplin (X2) secara persial berpengaruh positif dan signifikan terhadap Prestasi kerja pegawai pada Kantor Pekerjaan Umum Pelaksanaan Jalan Nasional Wilayah Provinsi Gorontalo. 
4. Pembinaan (X) Yakni Pembinaan Pendidikan dan Pelatihan (X3) secara persial berpengaruh positif dan signifikan terhadap Prestasi kerja pegawai pada Kantor Pekerjaan Umum Pelaksanaan Jalan Nasional Wilayah Provinsi Gorontalo.

\section{Saran}

Dari hasil penelitian, maka dapat dikemukakan saran sebagai berikut:

1. Desain Aktivitas terkait dengan pembinaan yang ada pada Kantor Pekerjaan Umum Pelaksanaan Jalan Nasional Wilayah Provinsi Gorontalo mempunyai pengaruh yang cukup besar terhadap prestasi kerja. Bagi kantor atau dinas terkait hendaknya dapat mempertahan dan lebih meningkatkan program pembinaan karir yang ada dengan memberikan informasi secara transparan mengenai kriteria dan syarat yang diperlukan dalam pembinaan karir, karena program pembinaan karir dapat memberikan pengaruh dalam usaha peningkatan prestasi kerja pegawai dan juga dapat meningkatkan kemampuan pegawai yang nantinya berujung pada peningkatan prestasi kerja

2. Bagi peneliti selanjutnya, sebaiknya menambah variabel lain seperti penghargaan dan promosi yang mungkin dapat mempengaruhi prestasi kerja didunia kerja.

\section{DAFTAR PUSTAKA}

Abdurrahmat, Fathoni. 2010. Manajemen Sumber Daya Manusia.Bandung: Rineka Cipta.

A.Anwar Prabu Mangkunegara. 2010. Perencanaan Dan Pengembangan Sumber Daya Manusia, Edisi ke-2, Penerbit Rafika Aditama, Bandung. . 2012. Perencanaan Dan Pengembangan Sumber Daya Manusia, Edisi ke-2, Penerbit Rafika Aditama, Bandung.

Hasibuan Malayu SP. 2009. Manajemen Sumber Daya Manusia, Edisi Revisi, Cetakan ketigabelas, BumiAksara, Jakarta.

.2010. Manajemen Sumber Daya Manusia, Edisi Revisi, Cetakan ketigabelas, BumiAksara, Jakarta.

Hartati Sukirman dkk 2009. Administrasi Dan Supervisi Pendidikan. Yogyakarta : FIP Pres.

Hedjrachman Suad Husnan 2012. Manajemen Personalia. Edisi Ke-4. Yogyakarta : Penerbit BPFE.

Hidayat S. 2009. Pembinaan Perkotaan Di Indonesia. Tinjuan Dari Aspek Administrasi Pemerintahan. Bina Aksara : Jakarta.

Marwan Asri dan Budi. 2010. Pengelolaan Karyawan. BPFE : Yogyakarta.

Martoyo.Susilo..2011. Manajemen Sumber Daya Manusia,BPFE.Yogyakarta.

Mathis, Robert L. \& Jackson Jhon H. 2009. Manajemen Sumber Daya Manusia Jakarta :

Penerbit Salemba Empat.

. 2012. Manajemen Sumber Daya Manusia Jakarta : Penerbit Salemba Empat.

Matutina, Domi C. dkk. 2013. Manajemen Personalia. Jakarta : Rineka Cipta 


\section{. 2014. Manajemen Personalia. Jakarta : Rineka Cipta}

Nawawi Hadari. 2010. Manajemen Sumber Daya Manusia. Yogyakarta : Andi.

Pamudji. 2011. Pembinaan Perkotaan Di Indonesia. Bina Aksara. Jakarta.

Poerwadaminta. 2011. Kamus Umum Bahasa Indonesia. Jakarta : Kencana Prenada Media Group

Riduwan 2010, Metode Dan Teknik Penyusunan Tesis. Bandung : Alfabeta

Sadili, Samsudin. 2006. Manajemen Sumber Daya Manusia.Bandung : Pustaka Setia . 2010. Manajemen Sumber Daya Manusia. Bandung : CV. Pustaka Setia

Sugiyono.2010. Metode Penelitian Pendidikan Pendekatan Kuantitatif, kualitatif, dan R\&D. Bandung: Alfabeta

Sutrisno Edi, 2009. Manajemen Sumber daya Manusia. Edisi Pertama. Jakarta: Kencana Prenada Media group.

Sudjana, Ibrahim. 2010. Penelitian dan penilaian Pendidikan. Bandung : Sinar Baru Algensindo. . 2014. Penelitian dan penilaian Pendidikan. Bandung: Sinar Baru Algensindo

Tampubolon, Manahan.2012.Perilaku Organisasi.Jakarta: Ghalia Indonesia

Tangdilintin, Philip. 2010. Pembinaan generasi Muda. Kanisius: Yogyakarta.

Widjaja A.W. 1988. Administrasi Kepegawaian: Suatu Pengantar. Jakarta : Rajawali Press. 